\title{
ISOLATION AND SCREENING OF D-LIMONENE-RESISTANT MICROORGANISMS
}

\author{
Juliano Lemos Bicas*; Gláucia Maria Pastore \\ Laboratório de Bioaromas, Departamento de Ciência de Alimentos, Faculdade de Engenharia de Alimentos, Universidade \\ Estadual de Campinas, Campinas, SP, Brasil
}

Submitted: December 20, 2006; Returned to authors for corrections: April 02, 2007; Approved: July 27, 2007.

\begin{abstract}
This study reports the isolation of microorganisms that are resistant to environment containing limonene, the most important residue in the citrus industry. For the isolation, samples collected from strategic places of a citrus processing plant (yellow water, entrance and exit of the bagasse tank, effluent and deteriorated fruits found in bins, machine straps, fruit washers and plant floor), some citrus fruit and mint from local market were used. The samples were incubated in rotary shaker at $30^{\circ} \mathrm{C} / 150 \mathrm{rpm}$ for $48 \mathrm{~h}$ or 7 days in YM medium containing $0.1 \%$ limonene. Great part of the 112 strains recovered after $48 \mathrm{~h}$ and the 126 strains recovered after 7 days were identified as Gram positive bacilli, followed by Gram negative bacilli, yeasts and Gram positive cocci, besides five fungi. About half of the Gram positive and Gram negative bacilli and yeasts and some Gram positive Cocci were resistant to limonene concentrations up to $2 \%$ in the medium broth. Amongst them seventy were able to grow in mineral medium containing limonene as sole carbon source. The research described in this paper is the initial step for the exploration of flavor compounds production via biotransformation of limonene, a nonexpensive by-product of citrus industry.
\end{abstract}

Key-words: Limonene, industrial by-products, flavor, biotechnology.

\section{INTRODUCTION}

$D$-limonene is the most abundant monocyclic monoterpene in nature and represents more than $90 \%$ of orange peel oil (2). Its chemical structure is similar to many oxygenated monoterpenoids with pleasant fragrance and, therefore, $d$ limonene may be used in flavor industry as a precursor in the synthesis of those compounds (20). Beyond their desirable fragrances, some of these $d$-limonene oxygenated derivates, e.g. perillyl alcohol, carveol, carvone, geraniol and menthol, have shown biological activity in vivo against certain types of tumors, not only preventing the formation or progression of cancer, but also regressing the existing malignant tumors (8). These characteristics greatly enhance industrial interest in such compounds. In this context, biotransformation process emerges as an attractive alternative for the $d$-limonene transformation since, comparing to the traditional chemical methods, they proceed under mild conditions, have an elevated regio and enantioselectivety, do not generate toxic wastes and the products obtained might be labeled as "natural" $(13,17)$. In the scientific literature, the biotransformation of limonene by microorganisms has been well documented (12). However, a commercial process, which could be applicable and possess high productivity, is yet to be developed.

The main problems involved in monoterpene biotransformation processes are (i) the chemical instability of both precursor and product, (ii) the low solubility of the precursor, (iii) the high volatility of both precursor and product, (iv) the high cytotoxicity of both precursor and product and (v) the low transformation rates (18). The three first topics are very difficult to be overcome as they are related to physicochemical characteristics inherent to the system, but a good limoneneresistant strain screening might surpass the citotoxicity and the low transformation rates.

The interest in solvent-tolerant microorganism screening is increasing in the last years. The isolation of microorganisms

*Corresponding Author. Mailing address: Laboratório de Bioaromas - Departamento Ciência de Alimentos - Faculdade de Engenharia de Alimentos UNICAMP - Rua Monteiro Lobato, 80 CP 6121 cep 13083-862 Campinas, SP - Brasil. Tel.: (19) 3521-3887. E-mail: juliano@fea.unicamp.br 
from this extreme environment will enable innovations in the field of fermentation and might bring several benefits to industries (16). A solvent-resistant Pseudomonas putida strain for the limonene bioconversion has already been isolated from sludge (26).

Brazil is the major world producer of oranges, presenting bulk amounts of $d$-limonene at a low price (21). Consequently, the country has an enormous potential for exploration of viable biotransformation process. In this paper we describe the isolation and screening of microorganisms resistant to $d$ limonene and its use as sole carbon source, which is one of the main characteristics of a biotransforming agent. In future, the selected strains might be evaluated as their biotransformation capacity.

\section{MATERIALS AND METHODS}

\section{Samples}

The $d$-limonene source used in this study was citrus terpene (94\% $d$-limonene in GC, data not shown), a citric molasses oil gently supplied by Citrovita ${ }^{\circledR}$.

Samples were collected in a citrus processing plant (Citrovita ${ }^{\circledR}$ - Araras, SP, Brazil), where it is believed to have strains more adapted to limonene-containing environment. From the eight samples, four of them were liquids ("yellow water" YW -, "effluent" - E-, "entrance" - EN - and "exit" - EX - of the bagasse tank) while the other four were deteriorated semisolid fruits recovered from "orange bins" (OB - subdivided in five samples), "fruit washers" (FW - subdivided in four samples), "machine straps" (MS) and "plant floor" (PF subdivided in six samples). Vegetable samples (oranges, lime, mint) acquired in local market were also used in this study.

For microorganism isolation, the inoculum was prepared as follows: $\operatorname{mint}(\mathrm{M})$ : small branch crushed under sterile conditions; healthy orange (HO) (Citrus sinensis Osbeck), orange (Citrus sinensis Osbeck) with black dots (BD) and a rangpur lime (RL) (Citrus limonia Osbeck): $0.5 \mathrm{~cm} \times 0.5 \mathrm{~cm}$ pieces of peel and pulp, obtained under sterile conditions; liquid and semisolid samples: 2-3 loops with intercalated shaking.

\section{Isolation and cultivation}

Each inoculum described above was transferred to $250 \mathrm{~mL}$ Erlenmeyer flasks containing $50 \mathrm{~mL}$ of YM medium ( $1 \%$ glucose, $0.5 \%$ peptone, $0.3 \%$ malt extract, $0.3 \%$ yeast extract, $\mathrm{pH}$ not adjusted) and $50 \mu \mathrm{L}(0.1 \%, \mathrm{v} / \mathrm{v})$ of $d$-limonene, added to preselect limonene resistant strains. After $48 \mathrm{~h}$ or 7 days of cultivation in a rotary shaker at $30^{\circ} \mathrm{C} / 150 \mathrm{rpm}$, a loop of each flask was transferred to Petri dishes containing YM medium (2\% agar), following the streak plate method. The Petri dishes were incubated at $30^{\circ} \mathrm{C}$ until complete colonies growth, limited to 7 days. As each different colony appeared, these were transferred to $18 \mathrm{~mL}$ tubes with YM slant medium.
Fresh bacterial and yeasts colonies (24h) were observed in microscopes after Gram coloration to confirm that they were actually isolated. In negative cases, the material was streaked in Petri dishes once more.

\section{Selection}

One loop of each isolated strain was transferred to a $50 \mathrm{~mL}$ Erlenmeyer flask containing $10 \mathrm{~mL}$ of sterile YM medium and $200 \mu \mathrm{L}(2 \%, \mathrm{v} / \mathrm{v})$ of $d$-limonene. The flasks were inoculated in a rotary shaker $\left(30^{\circ} \mathrm{C} / 150 \mathrm{rpm}\right)$ for $48 \mathrm{~h}$. After this period, a $100 \mu \mathrm{L}$ sample of the culture broth was transferred to a Petri dish (YM medium) and homogenized with a Drigalski spatula. The culture growth was evaluated after $48 \mathrm{~h}$ at $30^{\circ} \mathrm{C}$ and all the strains that presented a satisfactory growth ( $>30 \mathrm{CFU})$ were considered resistant to $2 \%(\mathrm{v} / \mathrm{v})$ of limonene.

In succession, all the strains considered resistant were evaluated as utilization of limonene as sole carbon source. Thus, one $100 \mu \mathrm{L}$ aliquot of the culture broth from the last test was inoculated in a $50 \mathrm{~mL}$ Erlenmeyer flask containing $10 \mathrm{~mL}$ of mineral medium (in g/L: $\left(\mathrm{NH}_{4}\right)_{2} \mathrm{SO}_{4}=5.00 ;\left(\mathrm{NH}_{4}\right)_{2} \mathrm{HPO}_{4}=1.42$; $\mathrm{NaCl}=0.50 ; \mathrm{MgSO}_{4} .7 \mathrm{H}_{2} \mathrm{O}=0.40 ; \mathrm{CaCl}_{2}=0.60 ; \mathrm{KCl}=2.15$; $\mathrm{FeSO}_{4} .7 \mathrm{H}_{2} \mathrm{O}=0.01 ; \mathrm{ZnSO}_{4}=0.01 ; \mathrm{CuSO}_{4}=0.01 ; \mathrm{pH}$ not adjusted) and $100 \mu \mathrm{L}(1 \%, \mathrm{v} / \mathrm{v})$ of $d$-limonene. After $48 \mathrm{~h}$ incubation at $30^{\circ} \mathrm{C}$ and $150 \mathrm{rpm}$, a $100 \mu \mathrm{L}$ sample of the culture medium was homogenized in a Petri dish (YM medium) as already described. All the colonies that presented a satisfactory growth ( $>30 \mathrm{CFU}$ ) after $48 \mathrm{~h}$ at $30^{\circ} \mathrm{C}$ were considered as possible users of $d$-limonene as sole carbon source.

\section{RESULTS AND DISCUSSION}

\section{Isolated microorganisms}

The first digit in Tables 1 and 2 shows the number of isolated microorganisms classes in this study. This evaluation is based on the morphology of the colony and their characteristics in microscope after Gram coloration.

The majority of the microorganisms isolated were Gram positive bacilli (127 strains), followed by a similar amount of both Gram negative bacilli (44 strains) and yeasts (37 strains) and finally a lower number of Gram positive cocci (23 strains). Interestingly, very few fungi strains could be isolated (5 strains), even though they grow very well in YM medium. This could be explained by the competition that could occur between the microorganisms, which might inhibit fungal growth. Other possibility is that the fungi, when compared to bacteria and yeasts, are more susceptible to lower concentrations of $d$ limonene. Actually, limonene increases the fluidity of fungal membranes, which leads to a high unspecific membrane permeability and loss of membrane integrity (25).

The two incubation periods applied for the isolation, $48 \mathrm{~h}$ and 7 days, were chosen to favor the recovery of bacteria/ yeasts and fungal strains, respectively. In general, the number 
Table 1. Number of microorganism classes isolated from different sources ${ }^{a, b}$ after incubation $\left(48 \mathrm{~h} / 30^{\circ} \mathrm{C}\right)$.

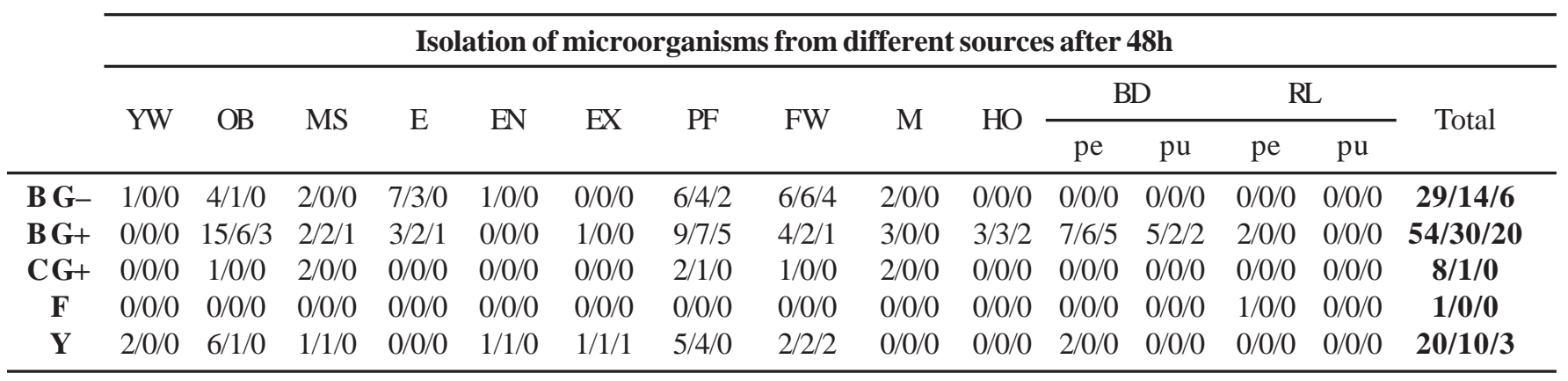

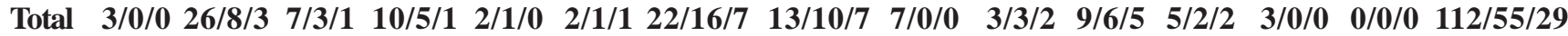

${ }^{a}$ YW: Yellow water; OB: orange bins; MS: machine straps; E: effluent; EN: entrance of bagasse tank; EX: exit of bagasse tank; PF: plant floor; FW: fruit washers; M: mint; HO: healthy orange; BD: orange with black dots; RL: rangpour lime; pe: peel; pu: pulp; B G-: Gram negative bacilli; B G+: Gram positive bacilli; C G+: Gram positive coccus; F: fungus; Y: yeast.

${ }^{b}$ The first, second and third digits represents, respectively, the number of isolated microorganisms, the number of limonene resistant microorganism and the number of microorganisms that grow in medium with limonene as sole carbon source.

Table 2. Number of microorganism classes isolated from different sources ${ }^{a, b}$ after incubation $\left(48 \mathrm{~h} / 30^{\circ} \mathrm{C}\right)$.

\begin{tabular}{|c|c|c|c|c|c|c|c|c|c|c|c|c|c|c|c|}
\hline \multicolumn{16}{|c|}{ Isolation of microorganisms from different sources after 7 days } \\
\hline & YW & $\mathrm{OB}$ & MS & $\mathrm{E}$ & $\mathrm{EN}$ & EX & $\mathrm{PF}$ & FW & M & $\mathrm{HO}$ & pe & $\overline{\mathrm{pu}}$ & pe & $\mathrm{pu}$ & Total \\
\hline B G- & $1 / 0 / 0$ & $0 / 0 / 0$ & $0 / 0 / 0$ & $3 / 1 / 1$ & $2 / 1 / 0$ & $1 / 0 / 0$ & $1 / 0 / 0$ & $8 / 4 / 3$ & $0 / 0 / 0$ & $0 / 0 / 0$ & $0 / 0 / 0$ & $0 / 0 / 0$ & $0 / 0 / 0$ & $0 / 0 / 0$ & $15 / 6 / 4$ \\
\hline B G+ & $0 / 0 / 0$ & $12 / 4 / 1$ & $4 / 4 / 1$ & $1 / 0 / 0$ & $1 / 1 / 1$ & $4 / 1 / 1$ & $12 / 10 / 9$ & $6 / 3 / 2$ & $7 / 1 / 1$ & $5 / 4 / 4$ & $12 / 9 / 8$ & $7 / 7 / 7$ & $1 / 0 / 0$ & $1 / 0 / 0$ & $73 / 44 / 35$ \\
\hline $\mathbf{C G}+$ & $0 / 0 / 0$ & $5 / 2 / 1$ & $0 / 0 / 0$ & $1 / 0 / 0$ & $5 / 0 / 0$ & $1 / 0 / 0$ & 2/0/0 & $1 / 0 / 0$ & $0 / 0 / 0$ & $0 / 0 / 0$ & $0 / 0 / 0$ & $0 / 0 / 0$ & $0 / 0 / 0$ & $0 / 0 / 0$ & $15 / 2 / 1$ \\
\hline $\mathbf{Y}$ & $1 / 0 / 0$ & $4 / 1 / 0$ & $1 / 1 / 0$ & $0 / 0 / 0$ & $1 / 1 / 0$ & $1 / 1 / 0$ & $4 / 4 / 1$ & $3 / 3 / 0$ & $1 / 1 / 0$ & $1 / 1 / 0$ & $1 / 1 / 0$ & $0 / 0 / 0$ & $0 / 0 / 0$ & $0 / 0 / 0$ & $17 / 14 / 1$ \\
\hline Total & $2 / 0 / 0$ & $22 / 7 / 2$ & $6 / 5 / 1$ & $5 / 1 / 1$ & $9 / 3 / 1$ & $7 / 2 / 1$ & $9 / 14 / 10$ & $19 / 10 / 5$ & $8 / 2 / 1$ & $6 / 5 / 4$ & $13 / 10 / 8$ & $7 / 7 / 7$ & $1 / 0 / 0$ & $2 / 0 / 0$ & $126 / 66 / 41$ \\
\hline
\end{tabular}

${ }^{a}$ YW: Yellow water; OB: orange bins; MS: machine straps; E: effluent; EN: entrance of bagasse tank; EX: exit of bagasse tank; PF: plant floor; FW: fruit washers; M: mint; HO: healthy orange; BD: orange with black dots; RL: rangpour lime; pe: peel; pu: pulp; B G-: Gram negative bacilli; B G+: Gram positive bacilli; C G+: Gram positive coccus; F: fungus; Y: yeast.

${ }^{b}$ The first, second and third digits represents, respectively, the number of isolated microorganisms, the number of limonene resistant microorganism and the number of microorganisms that grow in medium with limonene as sole carbon source.

of isolated microorganisms was higher for the samples incubated for 7 days. This longer period might favor stressed and sporulated microorganisms or those with a low growing rate. However, some microorganisms might enter in the death phase, which might difficult their isolation. As expected, the number of fungi was higher for samples incubated for 7 days.

Pulp samples were collected in order to isolate some fruit endophytes. As may be observed in Table 1, the only class of possible endophyte isolated after $48 \mathrm{~h} / 30^{\circ} \mathrm{C}$ were Gram positive bacilli from $\mathrm{BD}$ orange. On the other hand, after 7 days $/ 30^{\circ} \mathrm{C}, \mathrm{BD}$ orange resulted in seven Gram positive bacilli and two yeasts, while rangpour lime gave one Gram poitive bacilli and one fungi.

\section{Limonene resistant microorganisms}

The second digit in Tables 1 and 2 represents the number of limonene resistant microorganisms from those already isolated. It is worth noting that about one half of the isolated microorganisms resist to limonene concentrations up to $2 \%$, except for the Gram positive cocci, which appear to be more sensitive to limonene, and the fungi, that were not able to grow in high concentrations $(\geq 2 \%)$ of limonene. In his study, Abraham (1) reported that the taxonomic position of a strain is related to its enzymatic activity on terpenoid hydroxylation, but the substrate toxicity could not explain the difference. Thus, substrate resistance does not guarantee a high biotransformation 
activity, but it is an essential characteristic to a biotransforming agent.

Generally, the minimum inhibitory concentration (MIC) of limonene against some bacteria and yeasts are lower than $2 \%$ (14), although some fungi, e.g. Penicillium digitatum, presents only a small reduction on its bioconversion activity in concentrations of 4-8\% limonene (27) and some bacteria, e.g. Pseudomonas sp., might have no growth inhibition in concentrations of up to $10 \% \alpha$ - or $\beta$-pinenes (32). Furthermore, monoterpene toxicity might depend on their droplet size in suspension, as observed for Saccharomyces cerevisae (28). In biotransformation processes, the usual limonene concentration applied vary from 0.2 to $1 \%(3,10,11,22,24,27,29)$, although $0.2 \%$ limonene is the optimum concentration for its biotransformation to perillyl alcohol and $p$-ment-1-ene-6,8-diol using Pseudomonas putida (7) and is toxic to Bacillus stearothermophilus (4).

The methodology considered in this microorganism screening was similar to that applied by Chatterjee (6), who selected a $0,3 \%$ geraniol resistant soil bacteria for biotransformation trials. However, the solid phase microextraction (SPME) technique may also be useful for fungal screening (9). In this study, there were selected 121 microorganisms with higher MIC values, which makes them greatly attractive to biotechnological purposes.

\section{Use of limonene as sole carbon source}

From the total 238 isolated strains, 70 grew well in medium containing limonene as sole carbon source. The great majority of these microorganisms were Gram positive bacilli, followed by a small number of Gram negative bacilli and yeasts, and only one Gram positive cocci. As there were no limonene resistant fungi, none of them were tested as utilization of limonene as sole carbon source.

Proportionally, the recovery of strains able to use limonene as sole carbon source is favored by a 7 day-incubation and the most adapted microorganisms appear to be the Gram positive followed by Gram negative bacilli. This is in accordance with the bacterial biotransformation processes already published, as great part of them refers to Pseudomonas sp. $(3,7,10,11,19$, 26,32) and Bacillus sp. limonene conversions (4,5,15,23). Even though a larger part of the isolated yeasts resist to high limonene concentration, only a few (four for $48 \mathrm{~h}$ and one for 7 days) develop well in medium with this monoterpene as sole carbon source. This lower limonene metabolizing capacity might explain the few work published covering the yeasts-mediated biotransformation of limonene (30,31). The only isolated Gram positive coccus is of importance due to its biotransforming potential. As far as we know, there is no limonene biotransformation study described in literature using this class of bacteria.

Biotransformation processes with all the selected microorganisms are already under investigation in our laboratory in order to select the aroma-productive strains.

\section{ACKNOWLEDGEMENTS}

The authors acknowledge CAPES for the financial support and Citrovita ${ }^{\circledR}$ for the samples.

\section{RESUMO}

\section{Isolamento e Seleção de Microrganismos Resistentes ao $d$-Limoneno}

Este estudo relata o isolamento de microrganismos resistentes a ambientes contendo limoneno, o mais importante resíduo da indústria citrícola. Para o isolamento, foram utilizadas amostras colhidas de pontos estratégicos de uma indústria processadora de laranja (água amarela, entrada e saída do tanque de bagaço, efluente e frutas deterioradas encontradas nos bins, nas correias dos equipamentos, nos lavadores e espalhadas pelo chão), além de frutas cítricas e hortelã adquiridas em mercado local. Cada amostra permaneceu incubada a $30^{\circ} \mathrm{C} / 150$ rpm por $48 \mathrm{~h}$ ou 7 dias em meio YM contendo $0,1 \%$ de limoneno. Dentre as 112 linhagens obtidas com $48 \mathrm{~h}$ e as 126 com 7 dias, a grande maioria dos microorganismos isolados foram bacilos Gram positivos, seguidos por uma menor quantidade de bacilos Gram negativos, leveduras e cocos Gram positivos, além de cinco fungos. Cerca de metade das linhagens de bacilos Gram positivos e Gram negativos e de, leveduras e alguns de cocos Gram positivos resistiram à presença de até $2 \%$ de limoneno, dentre as quais 70 foram capazes de sobreviver em ambientes contendo limoneno como única fonte de carbono. $\mathrm{O}$ trabalho descrito nesse artigo representa o primeiro passo no desenvolvimento de processos de produção de compostos de aroma pela biotransformação do limoneno.

Palavras-chave: Limoneno, subprodutos industriais, aroma, biotecnologia.

\section{REFERENCES}

1. Abraham, W.R. (1994). Phylogenetic Influences in Microbial Hydroxylation of Terpenoids. World J. Microbiol. Biotechnol., 10(1), 88-92.

2. Bauer, K.; Garbe, D.; Surburg, H. (2001). Common Fragrance and Flavor Materials. Preparation, Properties and Uses. $4^{\text {th }}$ ed. Wiley VCH, Weinheim.

3. Cadwallader, K.R.; Braddock, R.J.; Parish, M.E.; Higgins, D.P. (1989). Bioconversion of (+)-Limonene by Pseudomonas gladioli. J. Food Sci., 54(5), 1241-1245.

4. Chang, H.C.; Oriel, P.J. (1994). Bioproduction of Perillyl Alcohol and Related Monoterpenes by Isolates of Bacillus stearothermophilus. J. Food Sci., 59(3), 660-662 and 686.

5. Chang, H.C.; Gage, D.A.; Oriel, P.J. (1995). Cloning and Expression of a Limonene Degradation Pathway from Bacillus stearothermophilus in Escherichia coli. J. Food Sci., 60(3), 551-553.

6. Chatterjee, T. (2004). Biotransformation of Geraniol by Rhodococcus sp. Strain GR3. Biotechnol. Appl. Biochem., 39(3), 303-306. 
7. Chatterjee, T.; Bhattacharyya, D.K. (2001). Biotransformation of Limonene by Pseudomonas putida. Appl. Microbiol. Biotechnol., 55(5), 541-546.

8. Crowell, P.L. (1999). Prevention and Therapy of Cancer by Dietary Monoterpenes. J. Nutr., 129(3), 775S-778S.

9. Demyttenaere, J.C.R.; Van Belleghem, K.; De Kimpe, N. (2001). Biotransformation of (R)-(+)- and (S)-(-)-Limonene by Fungi and the Use of Solid Phase Microextraction for Screening. Phytochemistry, 57(2), 199-208

10. Dhavalikar, R.S.; Bhattacharyya, P.K. (1966). Microbiological Transformation of Terpenes: Part VIII - Fermentation of Limonene by a Soil Pseudomonad. Indian J. Biochem., 3(3), 144-157.

11. Dhavalikar, R.S.; Rangachari, P.N.; Bhattacharyya, P.K. (1966). Microbiological Transformation of Terpenes: Part IX - Pathways of Degradation of Limonene in a Soil Pseudomonad. Indian J. Biochem., 3(3), 158-164.

12. Duetz, W.A.; Bouwmeester, H.; Van Beilen, J.B.; Witholt, B. (2003). Biotransformation of Limonene by Bacteria, Fungi, Yeasts and Plants. Appl. Microbiol. Biotechnol., 61(4), 269-277.

13. Giri, A.; Dhingra, V.; Giri, C.C.; Singh, A.; Ward, O.P.; Narasu, M.L. (2001) Biotransformation Using Plant Cells, Organ Cultures and Enzyme Systems: Current Trends and Future Prospects. Biotechnol. Adv., 19(3), 175-199.

14. Griffin, S.G.; Whyllie, S.G.; Markham, J.L.; Leach, D.N. (1999). The Role of Structure and Molecular Properties of Terpenoids in Determining their Antimicrobial Activity. Flav. Fragr. J., 14(5), 322-332.

15. Gurajeyalakshmi, G.; Oriel, P. (1989). Isolation of Phenol-Degrading Bacillus stearothermophilus and Partial Characterization of the Phenol Hydroxylase. Appl. Environ. Microbiol., 55(2), 500-502.

16. Horikoshi, K. (1995). Discovering Novel Bacteria, with an Eye to Biotechnological Application. Curr. Opin. Biotechnol., 6(3), 292 297.

17. Janssens, L.; De Pooter, H. L.; Schamp, N.M.; Vandamme, E.J. (1992). Production of Flavours by Microorganisms. Process Biochem., 27(4), 195-215

18. Krings, U.; Berger, R.G. (1998). Biotechnological Production of Flavours and Fragrances. Appl. Microbiol. Biotechnol., 49(1), 1-8.

19. Mars, A.E.; Gorissen, J.P.L.; Van Den Beld, I.; Eggink, G. (2001) Bioconversion of Limonene to Increased Concentrations of Perillic
Acid by Pseudomonas putida GS1 in a Fed-batch Reactor. Appl. Microbiol. Biotechnol., 56(1-2), 101-107.

20. Matthews, R.F.; Braddock R.J. (1987). Recovery and Application of Essential Oils from Oranges. Food Technol., 41(1), 57-61.

21. Mazzaro, D. (2000). Orange Oil, D-limonene Market Unsettled Due to Brazil Delays. Chem. Market Rep., 258(4), 18.

22. Menéndez, P.; García, C.; Rodríguez, P.; Moyna, P.; Heinzen, H. (2002). Enzymatic Systems Involved in D-limonene Biooxidation. Braz. Arch. Biol. Tech., 45(2), 111-114.

23. Natarajan, M.R.; Lu, Z.; Oriel, P. (1994). Cloning and Expression of a Pathway for Benzene and Toluene from Bacillus stearothermophilus. Biodegradation, 5(2), 77-82.

24. Noma, Y.; Yamasaki, S.; Asakawa, Y. (1992). Biotransformation of Limonene and Related Compounds by Aspergillus cellulosae. Phytochemistry, 31(8), 2725-2727.

25. Onken, J.; Berger, R.G. (1999). Effects of $R$-(+)-Limonene on Submerged Cultures of the Terpene Transforming Basidiomycete Pleurotus saidus. J. Biotechnol., 69(2-3), 163-168.

26. Speelmans, G.; Bijlsma, A.; Eggink, G. (1998). Limonene Bioconversion to High Concentratiuons of a Single and Stable Product, Perillic Acid, by a Solvent-Resistant Pseudomonas putida Strain. Appl. Microbiol. Biotechnol., 50(5), 538-544.

27. Tan, Q.; Day, D.F.; Cadwallader, K.R. (1998). Bioconversion of (R)(+)-Limonene by P. digitatum (NRRL 1202). Process Biochem. 33(1), 29-37.

28. Uribe, S.; Peña, A. (1990). Toxicity of Allelopathic Monoterpene Suspensions on Yeasts. Dependence on the Droplet Size. J. Chem. Ecol., 16(4), 1399-1408.

29. Van Der Werf, M.J.; Swarts, H.J.; De Bont, J.A.M. (1999) Rhodococcus erythropolis DCL14 Contains a Novel Degradation Pathway for Limonene. Appl. Environ. Microbiol., 65(5), 2092-2102.

30. Van Dyk, M.S.; Van Rensburg, E.; Moleleki, N. (1998). Hydroxylation of (+)-Limonene, (-) $\alpha$-Pinene and (-) $\beta$-Pinene by a Hormonema sp. Biotechnol. Lett., 20(4), 431-436.

31. Van Rensburg, E.; Moleleki, N.; Van Der Walt, J.P.; Botes, P.J.; Van Dyk, M.S. (1997). Biotransformation of (+)-Limonene and (-)-Piperitone by Yeasts and Yeast-like Fungi. Biotechnol. Lett., 19(8), 779-782.

32. Yoo, S.K.; Day, D.F.; Cadwallader, K.R. (2001). Bioconversion of $\alpha-$ and $\beta$-Pinene by Pseudomonas sp. Strain PIN. Process Biochem. 36(10), 925-932. 